\title{
Damn! Starting at the bottom again!
}

\author{
Jan D. Galla, MD, PhD
}

\author{
From the Department of Cardiothoracic Surgery, Englewood Hospital and Medical Center, Englewood, NJ. \\ Disclosures: Author has nothing to disclose with regard to commercial support. \\ Received for publication May 24, 2017; accepted for publication May 30, 2017; available ahead of print July 6, \\ 2017. \\ Address for reprints: Jan D. Galla, MD, PhD, Department of Cardiothoracic Surgery, Englewood Hospital and \\ Medical Center, 350 Engle St, Englewood, NJ 07631 (E-mail: Jan.Galla@EHMChealth.org). \\ J Thorac Cardiovasc Surg 2017;154:1343-4 \\ $0022-5223 / \$ 36.00$ \\ Copyright (C 2017 by The American Association for Thoracic Surgery \\ http://dx.doi.org/10.1016/j.jtcvs.2017.05.095
}

High school senior, college senior, fourth-year medical student, chief resident in surgery, FINALLY, chief resident in thoracic surgery. BMOC (Big Man On Campus) each time, only to start down at the bottom again next year. Well, here you go again! Only this time, instead of narrowing your focus in progressively smaller areas of concentration, a whole new world of challenges exists in areas to which you might never have had exposure. And if you thought discerning cephalad from caudad was difficult in freshman anatomy or remembering the anatomic relationships of the right hilar structures was vexing, then you've absolutely going to love learning the language(s) and intricacies of the business (financial, marketing, quality control), legal (contracts, leases, malpractices), administrative (committees, working groups, task forces), social (referrals, consults, bedside mannerisms and family interactions), and personal (financial planning, debt repayment, family, relaxation) facets that await you as a practicing thoracic surgeon. Remarkably, there is yet little formal preparation offered in most training programs, although a number of medical schools and some residencies now make either combined degrees (MD/MBA, MD/JD) or offer within the training programs exposure to business aspects of setting up a practice. And, within your formal training, you have surely developed (or learned haw) methods to favorably interact with referring colleagues via consultations, hallway queries, or even lunch time B.S. sessions. Yet, still....

In the current issue of the Journal, Hayanga and Amin ${ }^{1}$ offer insights into potential areas of pitfalls and weaknesses to which the newly minted surgeon might pay particular attention. Broken down into 5 broad areas, the authors (in a very abbreviated form) describe some of the salient aspects of quality, administrative responsibilities, political assessment, financial, and academic/research of which a new surgeon should be cognizant. Although limited in discussion because of space considerations and with a mildly academic-appointment view, many of their topics translate well into private practice as well. As the authors correctly note, many of these considerations are never, or at best, rarely formally taught and although one develops methods of doing consultations and interacting with referring consider: first maxim.

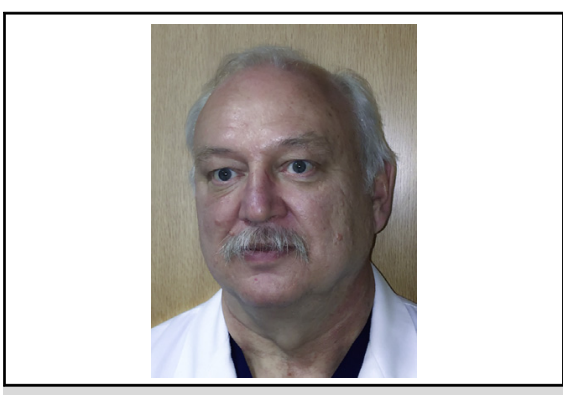

Jan D. Galla, MD, PhD

Central Message

Transitioning from resident to attending surgeon can be a challenging experience, one for which we are not well trained or prepared. Some guidelines to make this transition easier are presented.

See Article page 1340.

colleagues, there is pitifully little in the medical literature to help one's future development. Similarly, in the private sector, although a cottage industry has developed to help general surgeons build their practices, ${ }^{2-4}$ there is little to be found to assist the fledgling thoracic surgeon.

For their efforts in attempting to shed light on the taxing first few years of practice, Hayanga and $\mathrm{Amin}^{1}$ are to be commended, and reading their paper should be recommended to all about to begin their practice. This reviewer would argue, however, that their concluding 2 sentences should be elevated to the most prominent consideration, as might be listed below (as well as a few simplified suggestions) to

1. The patient ALWAYS comes first. We've all be taught this from day 1; we all talk about it and we all try to live it. Primum non nocere. ${ }^{5}$ We must, however, acknowledge that there are times when this is exceptionally difficult, as when the patient stubbornly refuses to improve despite your best efforts, or the blood keeps coming up the bronchoscope without any obvious source, or he or she just won't separate from the pump despite a great operation, etc. Frustration can quickly grind away at your best intentions, and it is at these times that you need to be especially true to the patient-comes-

2. Know your limitations. Dirty Harry ${ }^{6}$ was right: It is all so easy to get in over your head if not careful and circumspect. Coming out of a senior position in residency 
where you were probably working routinely with the most senior and experienced surgeons of the group, performing complex, challenging cases seemingly routinely with great results, it is easy to find yourself in deep (trouble) attempting similar cases by yourself with a staff that might not be familiar with the procedure and/ or your operating room habits. Moderation at first is well advised; make use of the resident "gray hairs" of the group and respect their counsel and experience/ expertise. It will save you a lot of grief in the long run.

3. Play nice with other children. Although we may all have heard the adage "You can always tell a (insert cardiologist/pulmonologist/internist), you just can't tell them much," rest assured our medical colleagues have a similar adage for (insert cardiac/thoracic/vascular) surgeons. Although our referring physicians might not see a particular situation in the same way we do, their views are based on years of training parallel tours, and sometimes their view allows us to think out of the box to arrive at a solution. The referrals will quickly diminish if a high-handed air of superiority, or even a basic lack of courtesy, is all your colleagues ever see. Treat them well, help them out when necessary, and they'll keep you busy with cases. Seek out the youngest, newest members of the medical groups-they'll be looking for someone on our side with whom they can build relationships. Keep in mind that it's unlikely you'll be seeing referrals from the chief of cardiology, who will continue to use the more senior surgeons, nor will you be likely to disrupt established referral patterns. These things will come: Be patient.

4. Don't neglect the little people. Hospitals and operating rooms are run by teams, many of them. Most of those teams' members rarely get praise or recognition and more often than not, abused by many. A modicum of acknowledgement can go a long way and pay repeating benefits that will only make your life easier (a box of doughnuts or a tin of cookies left open in a conspicuous place works wonders).

5. Not everyone is as smart or learned as you, but you don't know it all. Teaching and instruction can be one of the joys and rewards of being an attending: Embrace and enjoy any opportunity that presents itself, whether it be student (even undergraduate or high school), resident, fellow, nurse, or others. Sometimes community lectures are requested - these can not only be fun but a great opportunity for some public relations and free advertising for both yourself/your group and the hospital. Similarly, the chance to do research and/or professional writing need not be limited to the ivory tower crowd: See something unusual in a case? Write it up, present it to your monthly mortality and morbidity conference. Want to look into a pattern of events that you've noticed? Draw up an institutional review board proposal and methodically collect the data. Journals will publish meaningful work from private practitioners as well as the academic powerhouses. Not only will you be contributing to the advancement of the specialty, but you'll also learn something in the process.

6. Get involved. Your practice, the operating room, and the hospital don't run by themselves, and the administrators/ superiors are not mind readers. Pick an activity or committee that interests you and pitch in. You can make your voice heard, help effect change, and just might be able to head off and ill-advised position/policy or two. If you're not involved, you might be part of the reason those unreasonable rules came into being.

7. Lastly, don't forget yourself. Altruism is great, but if you are too overextended, your life will become a shamble. Make time to relax, unwind, decompress. Take a break now and then; make time for your friends, significant other, your family. Neglect any of those groups, and you'll find it's awful lonely out there. Be generous with your professional time and skills but don't get taken advantage of: You've worked long and hard to become what you are-you are entitled to appropriate reward and compensation. Have a good financial advisor and/or medical contract attorney at your disposal. You'll find it's worth the expense. And make sure you have a hobby or other outside interest-you need something to get your mind away from work now and then.

Our training programs continue to evolve, to change, ${ }^{7}$ yet there are many challenges to transitioning from resident to attending surgeon. The process can be adventurous, exciting, and exhilarating; after all, you've done similar challenges many times before. Just have a plan.

\section{References}

1. Hayanga JWA, Amin P. Setting out into practice: preparing for the future, today. J Thorac Cardiovasc Surg. 2017;154:1340-2.

2. Provider Services Nationwide LLC. Available at: http://www.physician practicestartup.com/default.aspx?gclid=CL_Cg7ywhtQCFZxLDQod9CYIbQ. Accessed May 25, 2017.

3. Practice Setup. Available at: http://practicesetup.com/starting-a-medical-practice aspx?gclid=CLWhs9-whtQCFc-KswodqP8Fyw. Accessed May 25, 2017.

4. Uzialko AC. How to open a private medical practice, step by step. Business News Daily. Available at: http://www.businessnewsdaily.com/8910-opening-a-medicalpractice.html. Accessed May 25, 2017.

5. Smith CM. Origin and uses of primum non nocere-above all, do no harm! J Clin Pharmacol. 2005;45:371-7.

6. Magnum Force. 1973. Available at: http://www.quotes.net/movies/7080. Accessed May 28, 2017.

7. Zeigler S. 2015 Minimizing and Maximizing: The Future of Cardiothoracic Surgery Training and Practice. Available at: http://www.acc.org/latest-in-cardiology/ articles/2015/04/29/09/41/minimizing-and-maximizing. Accessed May 25, 2017. 